\title{
Reseña: Nuevo coronavirus y buen gobierno. Memorias de la pandemia de COVID-19 en Perú de Edilberto Jiménez
}

\section{María Eugenia Ulfe}

Pontificia Universidad Católica del Perú doi: 10.46476/ra.v2i1.110

Edilberto Jiménez. Nuevo coronavirus y buen gobierno. Memorias de la pandemia de COVID-19 en Perú. Lima: IEP, Embajada de España, 2021

Edilberto Jiménez no es solo un conocido artista retablista ayacuchano, él es un antropólogo. Formado en Antropología en la Universidad Nacional de San Cristóbal de Huamanga, Edilberto ha realizado trabajo antropológico desde sus años cuando se encargaba del programa de radio y realizaba entrevistas en una ONG sobre desarrollo agrario en Ayacucho, hasta el recojo de testimonios para la Comisión de la Verdad. Este libro, conformado por 100 dibujos, muestra a Jiménez como el etnógrafo quien sale a recorrer el distrito limeño de San Juan de Lurigancho en donde reside. Lo recorre con ojos críticos, deteniéndose a observar críticamente y registrar mediante sus dibujos lo que iba viendo en sus caminatas por Casuarinas, Gran Chimú, Zárate, Las Flores, Mangomarca, Bayóvar, Arriba Perú, 15 de Junio, San Salvador, Jicamarca, Pedregal, entre otros. Viajó también a Ayacucho y volvió a Chungui en la provincia de La Mar donde años antes había realizado impresionantes dibujos y retablos ${ }^{1}$.

1. Véase: Jiménez, Edilberto. Chungui. Violencia y trazos de memoria, primera edición, Lima, COMISEDH, 2005. Chungui. Violencia y trazos de memoria, Segunda edición, Lima, IEP, COMISEDH, 
El dibujo es muchas veces una de las primeras etapas en el desarrollo de un retablo, a veces es un dibujo impreso como el de este libro, otras veces se trata de una imagen mental, que luego se plasma en una caja de madera y en figuras moldeadas a mano de cola y tiza. La observación es una forma de registro y descripción, quizás de la más importantes en la etnografía. Edilberto trasciende disciplinas. Transita de la observación etnográfica detenida y cuidadosa, al dibujo como técnica de registro, y quizás más adelante, que no sorprenda que estos dibujos pasen a un cajón de retablos.

Como buen etnógrafo, la observación es lo que le permite producir conocimiento desde la descripción. Ya que a través de esta podemos conocer, recoger a través del mirar, detenernos a conversar, preguntar y recoger también las voces de las personas. Eso hace Edilberto en este libro. No son las estadísticas de muertes que recibimos todos los días a través de los boletines del Ministerio de Salud. Tampoco las historias que llegan en los noticieros. Son las historias de desgarramiento de un tejido social que le permiten a Jiménez, por ejemplo, trazar un paralelismo entre los años del conflicto y lo que vivimos durante las semanas de cuarentena más dura con toques de queda militarizados, una vigilancia excesiva, detenciones, un lenguaje de guerra, «ganar en esta batalla» (p. 28).

El primer dibujo captura el momento cuando el entonces presidente Martín Vizcarra anuncia la cuarentena en la quincena de marzo del 2020 (p.23). La escena del televisor en la que se observa al presidente acompañado de sus ministros con banderas del Perú contrasta dramáticamente con la incertidumbre y el temor en los ojos de la familia que recibe la noticia - la madre cocinando se detiene a mirar la televisión, los niños paran sus juegos, el esposo voltea a mirar-. La pandemia puede ser el gran acontecimiento que desnuda la precariedad del Estado y las grietas y hondas desigualdades sociales.

Casi al comienzo de la pandemia, la filósofa estadounidense Judith Butler escribía sobre el virus que no vemos, que se extiende, contamina, avanza y contagia ${ }^{2}$. Pero, sobre todo, ella hacía hincapié en que hubo quienes nunca pudieron guarecerse de este y tuvieron que mantenerse en la calle trabajando sin condiciones laborales - el virus volvió también evidentes las relaciones laborales de explotación que recae en ciertos grupos y sectores sociales-.

Al mismo tiempo, Jiménez muestra, a través de este libro, una obra personal y colectiva. Una obra que recurre, como las mismas ollas comunes, a ese esfuerzo

DED, 2009. Jurgen Golte \& Ramón Pajuelo (editores), Universos de Memoria. Aproximación a los retablos de Edilberto Jiménez sobre la violencia política, Lima, IEP, 2012.

2. Véase Judith Butler, «Human Traces on the Surfaces of the World», ConTactos, 2020. Disponible: https://contactos.tome.press/human-traces-on-the-surfaces-of-the-world/ 
colectivo y solidario que se alza, precisamente, como fuerza de resistencia frente a la inercia del propio Estado. Este es un libro que tiene también esa dimensión colectiva, ya que con Jiménez dibujan también su hijo, sus sobrinos, sus hermanos $\mathrm{y}$ varios de los que recoge provienen de amistades y de colegas.

El coronavirus «es visibilizado como el monstruoso murciélago, con ojos de espanto, con dientes degolladores, o como el succionador de sangre. Luego está esa cabeza redonda, donde pareciera estar con los clavos hundidos, que solo son sus coronas». (p. 26). Es un monstruo invisible, que llega por el aire, e hizo que ante la poca acción del Estado sean las propias comunidades que implementen sus protocolos y estrategias de cuidado. El otrora puente Kutinachaka que aparece en el documental del director Sebatian Jallade, Nada queda sino nuestra ternura (2017), mostrándolo como un lugar de tránsito de migrantes, quedaba cerrado para proteger Chungui del virus (p. 87).

Por momentos, también los dibujos de Edilberto cumplen otra función. Quizás sin proponérselo, pero es algo que el arte también hace, nos permite mediante el recuerdo conmemorar a quienes no están. La carta de la madre del médico ayacuchano Neil Alarcón, los entierros en cementerios, los costos y castigos por no tener donde enterrar a tus muertos, la falta de oxígeno, los hospitales llenos de pacientes... el llaqtamaqta de Chungui que canta:

«Oh, habrá sido el rico el causante, qué habrá sido el causante, para que solo los pobres puedan llorar, para que solo los pobres puedan morir...» (p. 145)

Resistir es una forma precisamente de luchar contra esa tendencia y percepción extendida. En el bajo Marañón donde he comenzado a trabajar desde hace dos años, nos contaban que sobrevivir es precisamente enfrentarse a los poderosos. Allí también, como cuenta Edilberto para Ayacucho, recurrieron a sus hierbas y plantas para curarse. Edilberto narra la historia de Honorato Sicha Ataupilco de Vinchos, quien se bañó en pichi, la tomó, se durmió y tuvo un sueño con una mujer que le decía que olía mal y que se iba por apestoso - esa mujer era el coronavirus(p.220) y la orina la había corrido.

Sin perder el sentido del humor, Edilberto nos confronta en aquello que nos hemos convertido, astronautas en el espacio, las capas de mascarillas, los atuendos que algunos visten, los protectores faciales... el virus está también transformándose en la «enfermedad del miedo».

Edilberto es nuestro cronista contemporáneo. Ya sus retablos recrearon hechos de violencia tremendos, sucedidos en las décadas de 1980 y 1990. A través de sus 
dibujos y retablos retrató lo que vivieron chunguinos en ese tiempo. Y hoy al más puro estilo de Guamán Poma, escribe una carta a la sociedad y a nuestras más grandes autoridades para decir en voz alta con su trazo y su pluma:

«Esto no es un país, es una fosa común con himno nacional» (p. 228).

A los muertos de los 1980 y 1990, se unen estos miles de muertos dejados por la Covid-19 y el abandono del Estado, que con treinta de años de crecimiento económico no fue capaz de proveer camas de cuidados intensivos ni oxígeno a sus ciudadanos. Jiménez permite que sus dibujos hablen sobre estas pérdidas y retraten la desigualdad de manera descarnada. Este libro se une a sus clásicos sobre violencia y memoria, la pandemia se ha convertido en un ciclo de violencia sin tregua en muchos hogares y quedará como huella indeleble en nosotros. Por ello, este libro se vuelve de indispensable lectura para no solo para comprender la pandemia, sino las sucesivas violencias sobre ciudadanos y ciudadanas peruanas. 